\title{
Preparation and Characterization of Monoclonal Antibodies to a Butyrivibrio sp. and Their Potential Use in the Identification of Rumen Butyrivibrios, Using an Enzyme-linked Immunosorbent Assay

\author{
By GEOFFREY P. HAZLEWOOD,${ }^{1 *}$ MICHAEL K. THEODOROU,$^{3}$ \\ AMANDA HUTCHINGS, ${ }^{2}$ DAVID J. JORDAN ${ }^{1}$ AND \\ GIOVANNI GALFRE2 \\ ${ }^{1}$ Department of Biochemistry and ${ }^{2}$ Monoclonal Antibody Centre, AFRC Institute of Animal \\ Physiology, Babraham Hall, Babraham, Cambridge CB2 4AT, UK \\ ${ }^{3}$ The Animal and Grassland Research Institute, Hurley, Maidenhead, Berkshire SL6 5LR, UK
}

(Received 15 May 1985 ; revised 22 July 1985)

\begin{abstract}
Antisera and monoclonal antibodies $(\mathrm{McAb})$ were prepared against the proteolytic rumen bacterium Butyrivibrio strain PI-7, and their reaction with bacterial antigens was quantified by using an enzyme-linked immunosorbent assay. A dye-release assay was developed to assess the binding of fixed bacterial cells to microtitration plates. Five McAb were screened against 15 type cultures representing other important rumen genera, five type cultures of the genus Butyrivibrio and 63 presumptive butyrivibrios, which were assigned to the genus on the basis of their biochemical and morphological characteristics. Antiserum was also screened against all strains of Butyrivibrio. Of all the bacteria tested, only six presumptive butyrivibrios cross-reacted with two or more McAb; six others cross-reacted with at least one McAb; 20 butyrivibrios, including three of the type cultures, cross-reacted with the antiserum. Binding-competition studies indicated that the $\mathrm{McAb}$ were directed against three different antigenic determinants. It is concluded that $\mathrm{McAb}$ have potential uses in grouping butyrivibrios and as a specific probe for a single strain.
\end{abstract}

\section{INTRODUCTION}

Members of the genus Butyrivibrio are among the most numerous and biochemically versatile rumen bacteria. They have been isolated from the forestomachs of different species of ruminants under a range of feeding regimes (Hungate, 1966; Roché et al., 1973) and are involved in the ruminal digestion of cellulose (Roché et al., 1973), the hydrolysis of dietary lipid (Hazlewood \& Dawson, 1975, 1979), the hydrogenation of polyunsaturated fatty acids (Polan et al., 1964) and in the production of butyrate and the interconversion of acetate and butyrate (Latham \& Legakis, 1976; Van Gylswyk, 1976). Butyrivibrios are heterogeneous with respect to substrates fermented, fermentation products (Bryant \& Small, 1956; Shane et al., 1969), nutritional characteristics (Byrant \& Robinson, 1962; Shane et al., 1969), and serology (Margherita \& Hungate, 1963; Margherita et al., 1964). A superficial subdivision of strains, based on nutritional requirements and the pattern of production of fermentation acids has been proposed (Shane et al., 1969), but no definitive taxonomic studies have been done. Currently there appears to be no basis for subdivision of the genus and if species other than the type species $B$. fibrisolvens exist, biochemical characterization alone does not provide a basis for their definition.

The potential application and use of antisera and immunofluorescence microscopy for the serological analysis of rumen micro-organisms has been investigated by a number of authors.

Abbreviations: FCS, foetal calf serum; McAb, monoclonal antibodies. 
Serological techniques showed that different morphological types of rumen bacteria, observed in vivo, were related to pure cultures of known micro-organisms cultured in vitro (Hobson et al., 1955, 1958, 1962; Hobson \& Mann, 1957). Serological evidence also led Jarvis (1967) to suggest the existence of two different species within the genus Ruminococcus, and enabled him and his co-workers to observe diurnal variations in ruminal numbers of cellulolytic cocci by using fluorescent antisera (Jarvis et al., 1967). Similarly, different serotypes were shown to exist in the genus Butyrivibrio, but within this large and heterogeneous group it was not possible to define taxa on the basis of antigenic relatedness (Margherita \& Hungate, 1963; Margherita et al., 1964). More recently, both antisera and McAb have been used to establish antigenic relationships and a rapid identification procedure for the methanogenic archaebacteria, some species of which comprise part of the normal rumen microflora (Conway de Macario et al., $1982 a, b, c$; Macario \& Conway de Macario, 1982).

In this paper we describe the production and characteristics of $\mathrm{McAb}$ raised against a rumen bacterium assigned to the genus Butyrivibrio. In undertaking the study, we had two principal objectives in mind. Firstly, to investigate whether, within a large and heterogeneous genus like Butyrivibrio, McAb could form the basis of a rapid identification procedure, enabling bacteria to be assigned to well-defined groups according to antigenic relatedness, and secondly, to determine whether such McAb would possess the specificity to permit subsequent identification and enumeration of selected species in natural populations, or mixed laboratory cultures.

\section{METHODS}

Rumen bacteria and culture conditions. Type cultures (15) representing the major genera of rumen bacteria were obtained from the National Collection of Dairy Organisms, from culture collections at the Animal and Grassland Research Institute and the Institute of Animal Physiology and from colleagues. Presumptive Butyrivibrio spp., including the proteolytic strain PI-7 which was used to raise antiserum and $\mathrm{McAb}$, were isolated from cows (Hazlewood et al., 1983), seaweed-eating Orkney sheep (Greenwood et al., 1983) and Svalbard reindeer (Orpin $e t$ al., 1985). All rumen bacteria were cultured at $39^{\circ} \mathrm{C}$ in medium $\mathrm{B}$, a semi-defined rumen fluid-free liquid medium (Lowe et al., 1985), by aseptic anaerobic techniques (Miller \& Wolin, 1974; Ogimoto \& Imai, 1981).

Overnight cultures $(10 \mathrm{ml})$ of the type species representing the major genera of rumen bacteria and of the Butyrivibrio strain PI-7 were used to inoculate $100 \mathrm{ml}$ of pre-warmed medium in a gas phase of $\mathrm{O}_{2}-\mathrm{free} \mathrm{CO}_{2}$ in $125 \mathrm{ml}$ serum bottles (Phase Separation Ltd). Cells were harvested by centrifugation $\left(3000 \mathrm{~g}, 15 \mathrm{~min}, 4^{\circ} \mathrm{C}\right)$ in the late exponential phase of growth. Presumptive butyrivibrios, other than strain PI-7, were cultured in medium B ( $9.5 \mathrm{ml}$ medium B plus $0.5 \mathrm{ml}$ inoculum) in screw-capped anaerobic culture tubes (Bellco Glass Inc.) and harvested as described above. Harvested cells were fixed by resuspending pellets in aqueous $0.85 \% \mathrm{NaCl}$ solution containing $1.6 \%(\mathrm{w} / \mathrm{v})$ formaldehyde (Conway de Macario $e_{t}$ al., 1982b) to an $\mathrm{OD}_{650}$ of 0.5 (Spectronic 20 spectrophotometer; Bausch \& Lomb). Suspensions of fixed bacteria were stored at $4{ }^{\circ} \mathrm{C}$.

A comparison of the ability of presumptive butyrivibrios and type cultures of the genus to ferment different carbon sources was made in liquid medium $B$ to which carbon sources $(0.4 \%$ final concentration) had been added according to the schemes of Hungate (1966) and Ogimoto \& Imai (1981). Growth was assessed either by measuring culture turbidity after 1,2 and $5 \mathrm{~d}$ incubation, or by comparing the concentration of volatile fatty acids in the culture supernatant with the concentration in uninoculated medium after $5 \mathrm{~d}$ incubation. Volatile fatty acids were determined as described by Lowe et al. (1985) and were used to assess growth on insoluble or optically opaque substrates such as amygdalin, glycogen, starch and xylan.

Binding of cells to micro-ELISA plates. A colorimetric procedure for determining whether fixed bacterial cells bind to micro-ELISA plates was based on the affinity of the dye PAGE blue G90 (BDH) for proteins (Bramhall $e t$ al., 1969). Plates were coated with bacterial cells and washed with phosphate-buffered saline (PBS) (NaCl, $0.85 \mathrm{~g} \mathrm{l}^{-1} ; \mathrm{Na}_{2} \mathrm{HPO}_{4}, 1.07 \mathrm{~g} \mathrm{l}^{-1} ; \mathrm{NaH}_{2} \mathrm{PO}_{4}, 0.039 \mathrm{~g} \mathrm{l}^{-1} ; \mathrm{NaN}_{3}, 0.5 \mathrm{~g} \mathrm{l}^{-1}$ ) containing $0.15 \%$ Tween 20 (PBST). PAGE blue G90 ( $100 \mu \mathrm{l}$ of $0.5 \mathrm{~g}^{-1}$ in $7 \%, \mathrm{v} / \mathrm{v}$, acetic acid) was added to each well and the plate was shaken for 15 min at room temperature (setting 3; Titertek plate shaker; Flow Laboratories). Excess dye was removed from each well by washing six times with $7 \%(\mathrm{v} / \mathrm{v})$ acetic acid. Dye bound to protein contained in the bacterial film was released by adding $100 \mu \mathrm{l}$ of methanol/water/conc. ammonia $(66: 3: 1$, by vol.) to each well and shaking the plate at room temperature for $15 \mathrm{~min}$. Colour liberated was measured at $620 \mathrm{~nm}$ (Multiscan MC plate reader; Flow Laboratories).

Preparation of antisera and hybrid myelomas and screening by ELISA. Fixed cells of Butyrivibrio PI-7 from $2 \mathrm{ml}$ cell suspension $\left(\mathrm{OD}_{650} 0.5\right)$ were washed and resuspended in $0.6 \mathrm{ml} \mathrm{PBS}$, prepared as described above but without the addition of Tween 20. After emulsifying in an equal volume of complete Freund's adjuvant, $200 \mu$ l samples of bacterial suspension were injected intra-muscularly into three female rats (strains DA, PVG and F344). Each rat 
was boosted at 2 month intervals with a subcutaneous injection of bacteria prepared as above, but in incomplete Freund's adjuvant. Test bleeds taken $10 \mathrm{~d}$ after the third boost were found by ELISA to contain antibodies. Six weeks later one of the rats (strain PVG) was injected intravenously with washed cells of strain PI-7 from $1 \mathrm{ml}$ of fixed cell suspension resuspended in PBS $(2 \mathrm{ml})$. The spleen was removed $3 \mathrm{~d}$ later, and the spleen cells were fused with cells of the rat myeloma line Y3 Agl. 2.3 (Galfre et al., 1979), as described by Galfre \& Milstein (1981). Then $14 \mathrm{~d}$ after fusion, supernatant fluids from confluent cultures were tested by ELISA for the presence of specific $\mathrm{McAb}$. Selected positive cultures were cloned in soft agar and individual clones picked up when at the stage of a few hundred cells.

Culture supernatants or rat antisera were screened for the presence of homologous antibodies using a solidphase ELISA, based on the quantitative immunoenzymic assay described for methanogens by Conway de Macario et al. (1982b), and similar in practice to the assay described by Archer (1984). A suspension of fixed bacterial cells $\left(\mathrm{OD}_{650} 0.5\right)$ containing $0.30 \mathrm{mg}$ dry weight cells m- $\mathrm{m}^{-1}$ was centrifuged $\left(3000 \mathrm{~g}, 15 \mathrm{~min}, 4^{\circ} \mathrm{C}\right)$ and the supernatant fluid was discarded. The pellet was routinely resuspended in five times the original volume of glassdistilled water and $0.1 \mathrm{ml}$ samples were pipetted into 96-well micro-ELISA plates (M129B Immulon, Dynatech, or Falcon 3912 MicroTest III flexible plates, Becton Dickinson). Plates were left at $39^{\circ} \mathrm{C}$ overnight during which time bacterial cells in the suspension dried on to the lower portion of the wall and the bottom of each well. When necessary, sensitized plates were wrapped in foil and stored at $4{ }^{\circ} \mathrm{C}$ in polythene bags until required; no deterioration was apparent after $14 \mathrm{~d}$ storage. Before use the bacterial film was washed three times with PBST and after blocking solution $(0.15 \mathrm{ml})$, comprising $10 \%(\mathrm{v} / \mathrm{v})$ foetal calf serum (FCS) in PBS, had been introduced into each well, the plate was incubated at $39^{\circ} \mathrm{C}$ for $1 \mathrm{~h}$. Each well was then washed three times with PBST as before, and antiserum or culture supernatant $(0.1 \mathrm{ml})$, diluted where necessary with PBS containing $2 \%(\mathrm{v} / \mathrm{v}) \mathrm{FCS}$, was added to each well and plates were incubated at $39^{\circ} \mathrm{C}$ for $1 \mathrm{~h}$. After washing (three times with PBST), anti-rat IgG conjugated to horseradish peroxidase (Miles Laboratories) and diluted 1000 to 2000 times with PBS containing $2 \%$ (v/v) FCS was added $(0.1 \mathrm{ml})$ to each well. Plates were incubated at $39^{\circ} \mathrm{C}$ for $1 \mathrm{~h}$. After washing (four times with PBST), chromogenic substrate $(0.1 \mathrm{ml})$, prepared by mixing glass-distilled water $(18 \mathrm{ml}), 1 \mathrm{M}$-sodium acetate/citric acid buffer, pH $6.0(2 \mathrm{ml}), N, N, N^{\prime}, N^{\prime}$-tetramethylbenzidine $\left(10 \mathrm{~g} \mathrm{l}^{-1}\right)$ in DMSO $(0.2 \mathrm{ml})$ and $6 \%(\mathrm{v} / \mathrm{v}) \mathrm{H}_{2} \mathrm{O}_{2}$ $(0.02 \mathrm{ml})$, was added to each well. Plates were incubated at room temperature for 10 to $20 \mathrm{~min}$ with continuous shaking and the reaction was terminated by adding $0.25 \mathrm{ml} 3 \mathrm{M}-\mathrm{H}_{2} \mathrm{SO}_{4}$. The absorbance of product formed in each well was measured at $450 \mathrm{~nm}$ (Multiscan MC plate reader). Wells to which antigen had been added, but which subsequently received pre-immune serum or uninoculated tissue culture medium, were included as blanks on all plates.

Radiolabelling of McAb and binding-competition assay. Cells from cloned lines were cultured in media containing $\left[{ }^{3} \mathrm{H}\right] \mathrm{lysine}$ and the secreted radiolabelled $\mathrm{McAb}$ were analysed by SDS-PAGE after reduction with 2mercaptoethanol (Kohler et al., 1976; Laemmli \& Favre, 1973). Before use in binding-competition assays, radioactive supernatants were dialysed against four changes of 100 vols of PBS.

The binding-competition assay evaluated the ability of a ${ }^{3} \mathrm{H}$-labelled $\mathrm{McAb}$ to bind to homologous antigen in the presence of varying concentrations of competing unlabelled McAb and was done in flexible 96-well PVC plates (Falcon 3912 MicroTest III) coated with fixed cells of Butyrivibrio PI-7. Remaining protein-binding sites were blocked and plates were washed as described previously. For each unlabelled McAb to be tested, serial dilutions in PBS containing $2 \%(\mathrm{v} / \mathrm{v})$ FCS were prepared to span a 50 -fold concentration range. Diluted McAb $(90 \mu \mathrm{l})$ were mixed in a sensitized well with $10 \mu \mathrm{l}^{3} \mathrm{H}$-labelled antibody containing 1.5 to $2.2 \times 10^{6} \mathrm{~Bq}$ and, after an initial period of shaking $\left(3 \mathrm{~min}\right.$ ), were incubated statically at $39^{\circ} \mathrm{C}$ for $1 \mathrm{~h}$. After removal of the antibody solution, wells were washed four times with PBST and blotted dry. The wells were then cut from the plate using an electrically-heated wire (Galfre \& Milstein, 1981), placed in scintillation vials and counted after the addition of $10 \mathrm{ml}$ scintillant (4 g PPO, $0.4 \mathrm{~g}$ POPOP, 1 litre toluene). Control wells contained only ${ }^{3} \mathrm{H}$-labelled antibody in PBS with $2 \%(\mathrm{v} / \mathrm{v}) \mathrm{FCS}$, and no competing unlabelled McAb.

\section{RESULTS}

\section{Enzyme-linked immunosorbent assay}

The ELISA was initially developed for screening antiserum samples prepared by immunizing rats with formalin-fixed Butyrivibrio PI-7 cells. Colour development due to non-specific adsorption occurred with pre-immune serum when diluted fivefold, but was negligible at a dilution of $10^{-3}$. In contrast, immune serum gave rise to appreciable colour development when diluted more than $10^{-4}$ (Fig. 1). In a typical assay, PVC wells were coated with $6 \mu \mathrm{g}$ antigen (whole cells), and $100 \mu \mathrm{l}$ antiserum (diluted $10^{-3}$ to $10^{-4}$ ), or culture supernatant fluid containing $\mathrm{McAb}$ (diluted 25 to 50 times) was sufficient to give absorbance values in the region of 1 . 


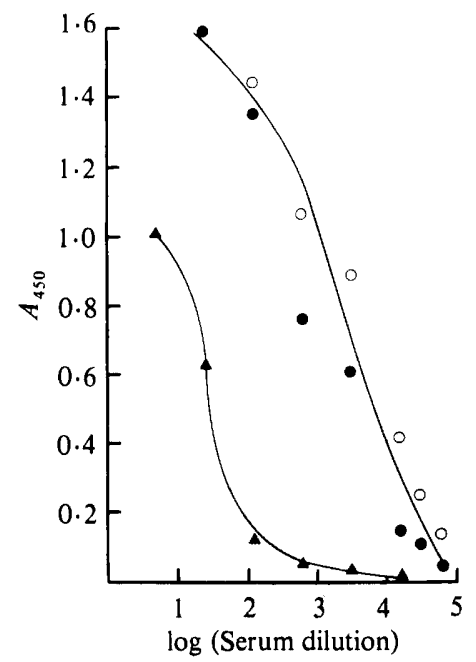

Fig. 1

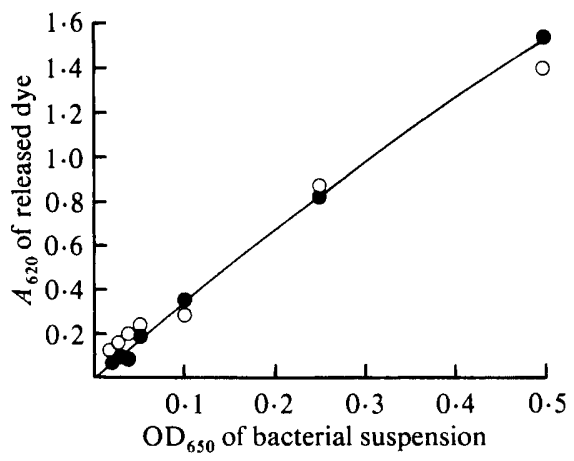

Fig. 2

Fig. 1. Detection of homologous antibodies by ELISA (as described in Methods). Immune sera $(\odot, \bigcirc)$ were obtained from rats which had been injected four times with antigen over a period of 6.5 months. Normal serum (A) was taken from a rat which had not been injected with antigen.

Fig. 2. Release of PAGE blue G90 by butyrivibrios coated on to microtitration plates. Plates were coated with strain PI-7 (O) or strain Bu49 (O), using cell suspensions of different concentrations. Each absorbance value for released dye is the mean of triplicate determinations.

To evaluate the ability of fixed cells of a number of different bacteria to cross-react with antiserum or McAb prepared against Butyrivibrio PI-7, it was necessary to determine first whether the cells of each test organism could bind to micro-ELISA plates. The uptake of PAGE blue G90 by the bacterial film and its subsequent release into the destaining solution proved in all cases to be a qualitative index of cell binding. For two butyrivibrios, strain PI-7 and strain Bu49, the uptake of dye and presumably the binding of cells to the PVC wells was comparable and almost linearly related to the concentration of cells in the sensitizing suspension (Fig. 2).

The ability of 10 different species of rumen bacteria to bind to the PVC wells was examined by using the dye-release assay. At a fixed coating concentration (twofold dilution of the working suspension), the mean absorbance of the released dye was $0.69 \pm 0.33$ (mean $\pm \mathrm{SD}, n=30$ ). In all instances, bacteria appeared to have coated the base of the wells but, in some, the film of cells was continuous and uniform while, in others, the major deposition of cells was in a ring around the edge of the base.

\section{Cell fusions and cloning}

Of the $96 \times 2 \mathrm{ml}$ cultures prepared from the fusion with cell line $\mathrm{Y} 3$ a total of 42 showed confluent growth of hybrids after $14 \mathrm{~d}$ and 24 of these were screened as positive by ELISA. Ten cultures whose supernatants consistently gave high absorbance values on screening by ELISA were cloned in soft agar and the clones were developed for screening and production of McAb. The distribution of absorbance values obtained on screening duplicate supernatants from a single batch of 120 clones by ELISA is shown in Fig. 3. On the basis of such information, five clones strongly positive $(++)$ for McAb production were selected for further investigation. These clones will be referred to as AFRC MAC 95 to 99.

\section{Binding-competition assays}

Competition between labelled and unlabelled McAb for binding to Butyrivibrio PI-7 cells indicated that the five McAb were of three types (Fig. 4). Each McAb strongly inhibited the binding of its ${ }^{3} \mathrm{H}$-labelled counterpart, but in all cases, dilution of unlabelled McAb between 20 


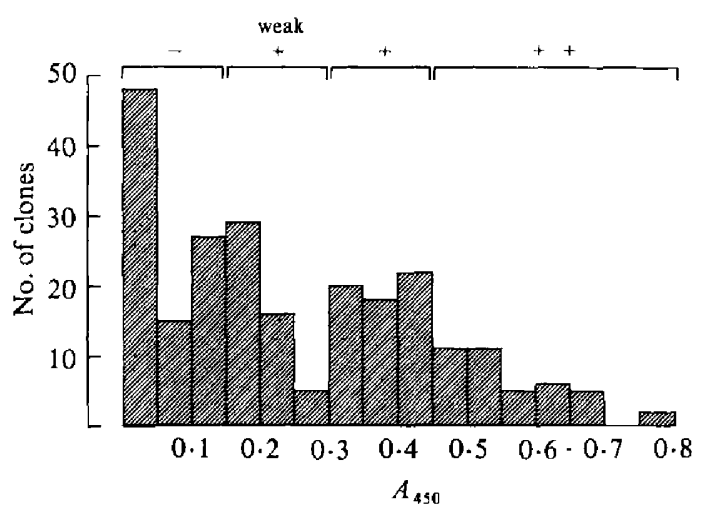

Fig. 3. Screening of culture supernatants by ELISA. Clones obtained from confluent hybrid cultures were assayed for the presence of antibody after 7 to $10 \mathrm{~d}$, as described in Methods. Background absorbance ranged from 0 to 0.15 and clones were scored weak,++ or ++ , according to the absorbance obtained in the ELISA ( $1-2$ times, 2-3 times or more than 3 times the background value, respectively).

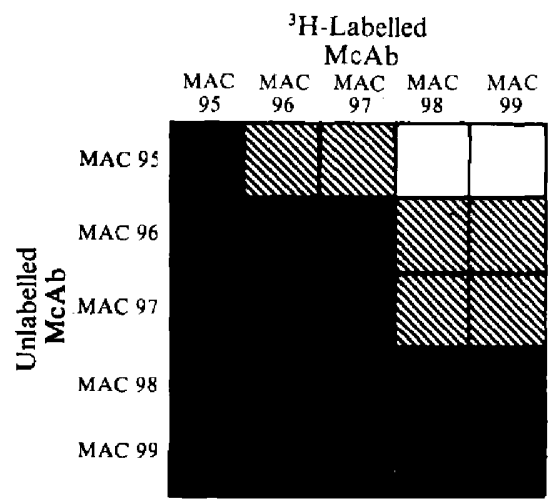

Fig. 4. Classification of McAb by binding-competition assay. Experiments were done as described in Methods. Degree of competition (percentage inhibition of binding) equates with extent of shading as follows: $\square,>50 \% ; \mathbf{\$}, 25-50 \% ; \square,<25 \%$

and 50 times eliminated competition. The first type (type I) was represented by MAC 95 which competed only weakly with MAC 98 and MAC 99 for binding to Butyrivibrio PI-7, but inhibited binding of MAC 96 and MAC 97 by 25 to $50 \%$. Type II McAb, MAC 96 and MAC 97 , inhibited binding of MAC 98 and MAC 99 by 25 to $50 \%$ and competed strongly ( $>50 \%$ inhibition of binding) with the others. MAC 98 and MAC 99 (type III) strongly inhibited binding of all ${ }^{3} \mathrm{H}$-labelled $\mathrm{McAb}$ to Butyrivibrio PI-7 cells.

\section{Cross-reaction of $M c A b$ with rumen genera other than Butyrivibrio}

All five McAb failed to cross-react with a selection of type cultures comprising Megasphaera elsdenii, Ruminococcus albus (two strains), Ruminococcus flavefaciens, 'Butyribacter' sp. (three strains; White, 1969), Selenomonas ruminantium (two strains), Bacteroides ruminicola subsp. ruminicola and subsp. brevis, Streptococcus bovis and 'Fusocillus' sp. (two strains; Kemp et al., 1975). A consistent but weak cross-reaction ( $<20 \%$ reaction obtained with Butyrivibrio PI-7) with Bacteroides amylophilus $\mathrm{H} 18$ was exhibited by MAC 95 , but not by the remaining four $\mathrm{McAb}$. 


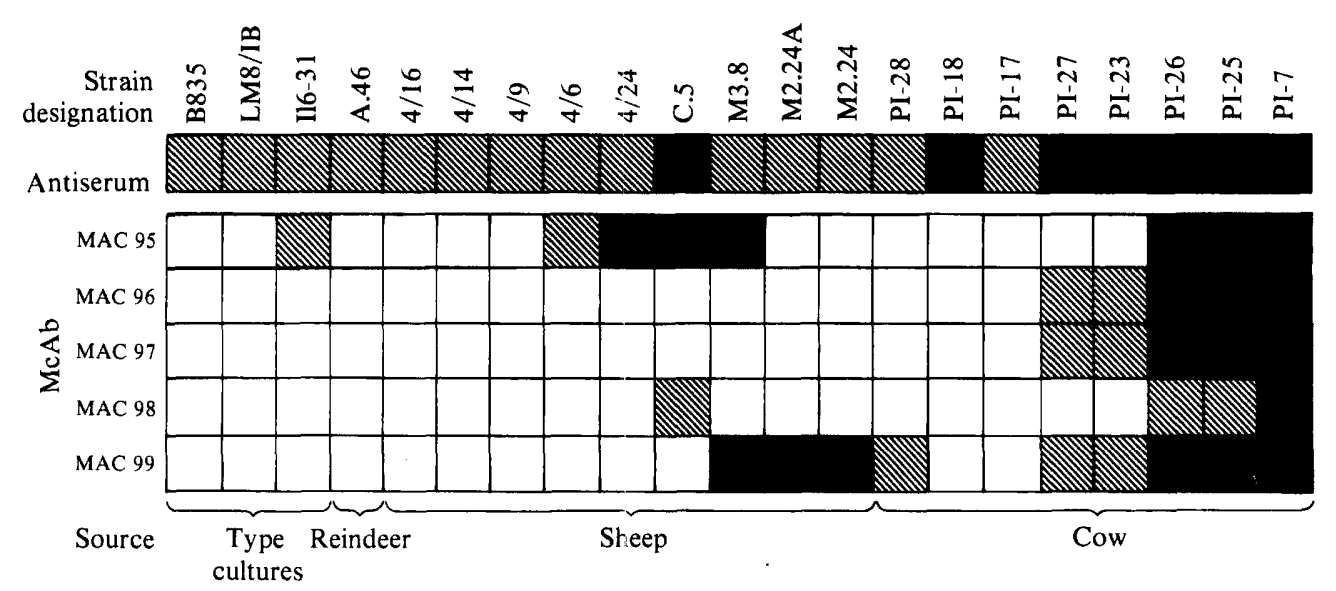

Fig. 5. Cross-reaction of presumptive butyrivibrios and type cultures with antiserum and $\mathrm{McAb}$ prepared against Butyrivibrio PI-7. Butyrivibrio cultures were screened by ELISA as described in Methods. In the absence of cross-reaction the $A_{450}$ was $<0.1(\square)$; positive cultures were scored $\mathbf{D}$ $\left(A_{450} 0.1\right.$ to 0.5$)$ or $\square\left(A_{450}>0.5\right)$.

\section{Cross-reaction of rat antiserum and $M c A b$ with presumptive butyrivibrios}

A total of 63 presumptive butyrivibrios were examined for cross-reaction with rat antiserum prepared against Butyrivibrio PI-7, using the ELISA. The butyrivibrios had been obtained primarily from cows (27 strains; Hazlewood et al., 1983), from reindeer (20 strains; Orpin et al., 1985) and from sheep (11 strains; Greenwood et al., 1983), but included five well-characterized (type) strains donated by other workers, namely strains Bu49, Nor37 and I16--31 (Sharpe et al., 1975) strain LM8/IB (Hazlewood \& Dawson, 1975) and strain B835 (Henderson, 1973). Of the 63 butyrivibrios, 21 gave a positive reaction with antiserum (Fig. 5). A strong reaction was observed between Butyrivibrio PI-7 and its homologous antiserum but five other bovine and one ovine isolate cross-reacted equally strongly. A weaker cross-reaction was evoked by 14 other isolates, including representatives of each of the sources listed (Fig. 5). Two of the type cultures, Bu49 and Nor37, did not cross-react with PI-7 antiserum.

Of the 63 butyrivibrios, 13, including Butyrivibrio PI-7, were able to bind one or more of the five $\mathrm{McAb}$ (Fig. 5). Depending on the extent of cross-reaction of each isolate with the panel of five $\mathrm{McAb}$, it was possible to divide these strains broadly into two groups. The first group (Fig. 5) cross-reacted extensively and contained strain PI-7 and four other strains which, like PI-7, were strongly proteolytic isolates from forage-fed cows (Hazlewood et al., 1983). The second group (Fig. 5) cross-reacted with MAC 95 or MAC 99 or both and contained six strains isolated from sheep and one strain isolated from a cow. The only type culture to bind McAb was I16-31 and this organism cross-reacted with MAC 95 only.

\section{Biochemical characteristics of presumptive butyrivibrios}

The obligately anaerobic Gram-negative rods which had been isolated from cows and sheep were assigned to the genus Butyrivibrio on the basis of biochemical characterization as described in standard texts (Hungate, 1966; Holdeman \& Moore, 1972; Ogimoto \& Imai, 1981; Table 1), and by comparison with strains whose status as Butyrivibrio spp. had been deduced previously, in some instances, by other workers (Bu49. Nor37 and I16-31, Sharpe et al., 1975; LM8/IB, Hazlewood \& Dawson, 1975; B835, Henderson, 1973). Table 1 lists the fermentation characteristics of these type cultures together with the characteristics of a selection of the presumptive butyrivibrios used in this study. All other isolates were tested similarly and, with the exception of minor differences in substrate fermentation patterns and some variation in the extent to which cells were curved, all isolates gave the same results and were assumed to be members of the genus Butyrivibrio. 


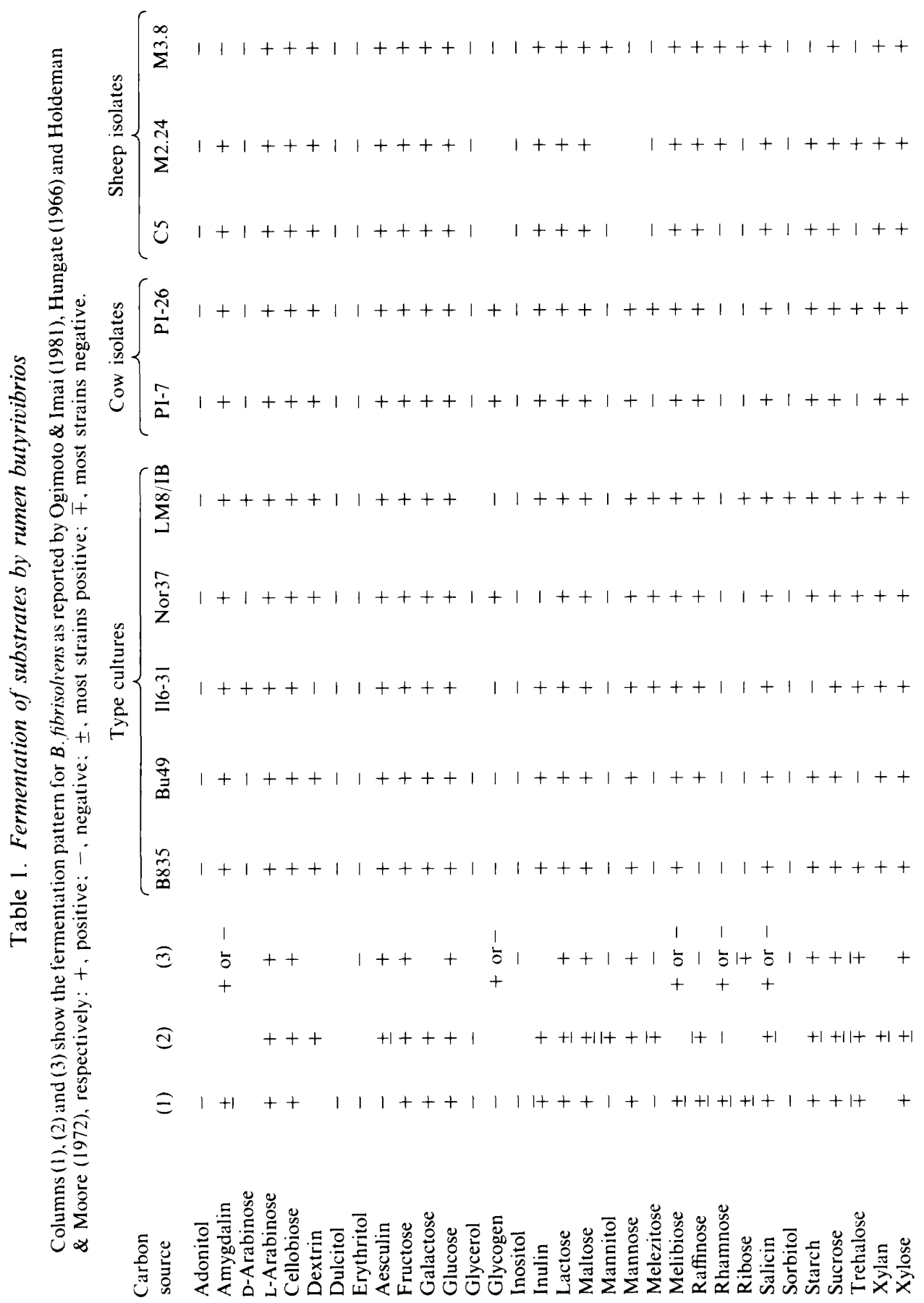


The ELISA described in this paper is clearly a rapid, sensitive and economical way of investigating and quantifying the reaction of a bacterial surface antigen with antiserum or McAb.

The results for the dye-release assay support the conclusion that the binding efficiency of bacterial cells is comparable for different species of bacteria. Data obtained with the two butyrivibrios (strains PI-7 and Bu49) indicate that bacterial films formed from similar concentrations of cells of closely related bacteria take up equivalent amounts of dye but for unrelated bacteria the assay provides only a qualitative indication of binding. PAGE blue G90 binds mainly, but probably not exclusively, to protein and it is not unreasonable to suppose that organisms of one genus may contain similar amounts of dye-binding components per unit dry weight, while dissimilar organisms may not.

Fixed cells of Butyrivibrio PI-7 were not very immunogenic in rats; three booster doses were required after the initial immunization before antibodies were detected. Three of the five type cultures and 17 of the 63 presumptive butyrivibrios cross-reacted with antiserum raised against Butyrivibrio PI-7. This lack of specificity manifest by antiserum prepared against a butyrivibrio is consistent with the findings of others (Margherita \& Hungate, 1963) and provides further evidence for the heterogeneous nature of this taxonomic group.

Five McAb raised against Butyrivibrio PI-7 were classified into three types on the basis of their competition for binding to cells of strain PI-7, indicating that there are at least three types of antigenic determinant on the surface of PI-7. Of the 20 butyrivibrios which cross-reacted with the antiserum, 12, including type culture I16-31, also gave a positive response with one or more of the five $\mathrm{McAb}$. These strains could be placed into two groups according to their pattern of crossreaction (Fig. 5). Reaction with MAC 96 and MAC 97, or with all McAb, was limited to four bacteria which, like strain PI-7, were proteolytic butyrivibrios isolated from the rumen of the two cows sampled in an intermixing group of three. These four strains (PI-23, PI-25, PI-26 and PI-27) did not differ greatly from PI-7 in biochemical tests. Considering the different species of ruminant from which cross-reacting butyrivibrios were obtained and the extreme geographical separation between animals from which cross-reacting organisms were isolated, it would appear that MAC 95 and MAC 99 may be directed against more widely distributed and conserved antigenic determinants, while MAC 96, MAC 97 and MAC 98 are specified by strain-specific determinants which may be unique to proteolytic butyrivibrios such as strain PI-7. The fact that rat antiserum cross-reacted with a further eight butyrivibrios, including two other type bovine cultures and two other proteolytic bovine isolates, indicated that the panel of five McAb used here does not represent every one of the surface antigens on strain PI-7. Loss of antigenic determinants by Butyrivibrio type cultures or the possibility that these apparently similar organisms are not in fact members of the genus Butyrivibrio could be regarded as alternative explanations. The weak cross-reaction between B. amylophilus strain H18 and MAC 95 was an unexpected observation. With this exception it appears that Butyrivibrio PI-7 and the type cultures of the other genera examined do not share antigenic determinants.

It has been concluded that $\mathrm{McAb}$ can complement standard biochemical procedures routinely used in identifying methanogenic archaebacteria, by specifying unique molecular markers for each taxonomic category (Jovell et al., 1981; Conway de Macario et al., 1981; Macario \& Conway de Macario, 1982). Results described here suggest that McAb prepared against a rumen butyrivibrio are directed either against highly strain-specific determinants (MAC 96, 97 or 98) or against determinants more generally distributed and conserved within the genus (MAC 95 or 99). The pattern of cross-reaction of presumptive butyrivibrios with this panel of McAb can clearly be used to subdivide isolates which appear to be identical when subjected to standard biochemical procedures. Whether antigenic relatedness is a valid characteristic for establishing further taxonomic divisions in the genus Butyrivibrio will depend on further studies with larger numbers of McAb. However, a relatively small panel of $\mathrm{McAb}$ clearly has the specificity necessary for construction of a probe to follow the fate of a specific organism, such as a genetically engineered bacterium, introduced in the rumen. In this context, the most useful $\mathrm{McAb}$ will be those which recognize genetically stable determinants. 
We would like to acknowledge Rebecca Morley and Sarah Hitching for skilled technical assistance, and Dr G. W. Butcher for helpful discussions.

\section{REFERENCES}

ARCHER, D. B. (1984). Detection and quantification of methanogens by enzyme-linked immunosorbent assay. Applied and Entironmental Microbiology 48, 797-801.

Bramhall, S., Noack, N., Wu, M. \& Loewenberg, J. R. (1969). A simple colorimetric method for determination of protein. Analytical Biochemistry 31, 146-148.

Bryant, M. P. \& Robinson, I. M. (1962). Some nutritional characteristics of predominant culturable ruminal bacteria. Journal of Bacteriology 84, 605 614.

Bryant, M. P. \& SMall, N. (1956). The anaerobic monotrichous butyric acid-producing curved rodshaped bacteria of the rumen. Journal of Bacteriology 72, 16-21.

Conway de Macario, E., Macario, A. J. L., Alito, A. E. \& Wolin, M. J. (1981). Monoclonal antibodies to methanogenic bacteria and techniques for immunochemical analysis of surface structures. Federation Proceedings 40, 1594.

Conway de Macario, E., Wolin, M. J. \& Macario, A. J. L. (1982a). Antibody analysis of relationships among methanogenic bacteria. Journal of Bacteriology 149, 316-319.

Conway de Macario, E., Macario, A. J. L. \& Wolin, M. J. (1982b). Specific antisera and immunological procedures for characterisation of methanogenic bacteria. Journal of Bacteriology 149, 320-328.

Conway de Macario, E., Macario, A. J. L. \& Wolin, M. J. (1982c). Antigenic analysis of Methanomicrobiales and Methanobrevibacter arboriphilus. Journal of Bacteriology 152, 762-764.

Galfre, G. \& Milstein, C. (1981). Preparation of monoclonal antibodies: strategies and procedures. Methods in Enzymology 73, 3-46.

Galfre, G., Milstein, C. \& Wright, B. (1979). Rat $\times$ rat hybrid myelomas and a monoclonal anti-Fd portion of mouse IgG. Nature, London 277, 131-133.

Greenwood, Y., Hall, F. J., Orpin, C. G. \& Paterson, I. W. (1983). Microbiology of seaweed digestion in Orkney sheep. Journal of Physiology 343, $121 \mathrm{P}$.

Hazlewood, G. \& Dawson, R. M. C. (1979). Characteristics of a lipolytic and fatty acid-requiring Butyrivibrio sp. isolated from the ovine rumen. Journal of General Microbiology 112, 15-27.

Hazlewood, G. P. \& Dawson, R. M. C. (1975). Isolation and properties of a phospholipid-hydrolysing bacterium from ovine rumen fluid. Journal of General Microbiology 89, 163-174.

Hazlewood, G. P., OrPin, C. G., Greenwood, Y. \& BLACK, M. E. (1983). Isolation of proteolytic rumen bacteria by use of selective medium containing leaf fraction 1 protein (ribulosebisphosphate carboxylase). Applied and Environmental Microbiology 45, 1780-1784.

Henderson, C. (1973). The effects of fatty acids on pure cultures of rumen bacteria. Journal of Agricultural Science 81, 107-112.
Hobson, P. N. \& ManN, S. O. (1957). Some studies on the identification of rumen bacteria with fluorescent antibodies. Journal of General Microbiology 16, 463471 .

Hobson, P. N., Mackay, E. S. M. \& ManN, S. O (1955). The use of fluorescent antibody in the identification of rumen bacteria in situ. Research (Correspondence Supplement) 8, S30-S31.

Hobson, P. N., Mann, S. O. \& Oxford, A. E. (1958). Some studies on the occurrence and properties of a large Gram-negative coccus from the rumen. Journal of General Microbiology 19, 462-472.

Hobson, P. N., ManN, S. O. \& Smith, W. (1962). Serological tests of a relationship between rumen selenomonads in vitro and in vivo. Journal of General Microbiology 29, 265-270.

Holdeman, L. V. \& MoORE, W. E. C. (1972). Anaerobe Laboratory Manual, 2nd edn. Blacksburg, Virginia: Virginia Polytechnic Institute and State University.

Hungate, R. E. (1966). The rumen bacteria. In The Rumen and Its Microbes, pp. 8-90. New York \& London: Academic Press.

JARVIS, B. D. W. (1967). Antigenic relations of cellulolytic cocci in the sheep rumen. Journal of General Microbiology 47, 309-319.

JARVIS, B. D. W., WILliams, V. J. \& ANNISON, E. F. (1967). Enumeration of cellulolytic cocci in sheep rumen by using a fluorescent antibody technique. Journal of General Microbiology 48, 161169.

Jovell, R. J., Conway de Macario, E., Alito, A. E. Wolin, M. J. \& Macario, A. J. L. (1981). Analysis of methane-synthesising bacteria by means of antisera and monoclonal antibodies. Federation Proceedings 40, 1124.

Kemp, P., White, R. W. \& Lander, D. J. (1975). The hydrogenation of unsaturated fatty acids by five bacterial isolates from the sheep rumen, including a new species. Journal of General Microbiology 90,100 104.

Kohler, G., Howe, S. C. \& Milstein, C. (1976). Fusion between Ig-secreting and non-secreting myeloma cell lines. European Journal of Immunology 6 , 292-295.

LaEmmLi, U. K. \& Favre, M. (1973). Maturation of the head of bacteriophage T4. Journal of Molecular Biology 80, 575-599.

LATHAM, M. J. \& LegaKis, N. J. (1976). Cultural factors influencing the utilization or production of acetate by Butyrivibrio fibrisolvens. Journal of General Microbiology 94, 380-388.

Lowe, S. E., Theodorou, M. K., Trinci, A. P. J. \& HESPELL, R. B. (1985). Growth of anaerobic rumen fungi on defined and semi-defined media lacking rumen fluid. Journal of General Microbiology 131 , 2225-2229.

Macario, A. J. L. \& Conway de Macario, E. (1982). The immunology of methanogens: a new development in microbial biotechnology. Immunology Today 3. 279-284. 
Margherita, S. S. \& Hungate, R. E. (1963). Serological analysis of Butyrivibrio from the bovine rumen. Journal of Bacteriology 56, 855-860.

Margherita, S. S., Hungate, R. E. \& Storz, H. (1964). Variation in rumen Butyrivibrio strains. Journal of Bacteriology 87, 1304-1308.

Miller, T. L. \& Wolin, M. J. (1974). A serum bottle modification of the Hungate technique for cultivating obligate anaerobes. Applied Microbiology 27, 985-987.

Ogimoto, K. \& ImaI, S. (1981). Rumen bacteria. In Atlas of Rumen Microbiology, pp. 71-125. Tokyo: Japan Scientific Societies Press.

Orpin, C. G., Mathiesen, S. D., Greenwood, Y. \& BLIX, A. S. (1985). Seasonal changes in the ruminal microflora of the high-arctic Svalbard reindeer (Rangifer tarandus platyrhynchus). Applied and Environmental Microbiology 50, 144-151.

Polan, C. E., McNeill, J. J. \& Tove, S. B. (1964). Biohydrogenation of unsaturated fatty acids by rumen bacteria. Journal of Bacteriology 88, 10561064.
Roché, C., Albertyn, H., Van Gylswyk, N. O. \& KisTNER, A. (1973). The growth response of cellulolytic acetate-utilizing and acetate-producing butyrivibrios to volatile fatty acids and other nutrients. Journal of General Microbiology 78, 253-260.

Shane, B. S., Gouws, L. \& Kistner, A. (1969). Cellulolytic bacteria occurring in the rumen of sheep conditioned to low-protein teff hay. Journal of General Microbiology 55, 445-457.

Sharpe, M. E., Brock, J. H. \& Phillips, B. A. (1975). Glycerol teichoic acid as an antigenic determinant in a Gram-negative bacterium Butyrivibrio fibrisolvens. Journal of General Microbiology 88, 355-363.

VAN GYLSWYK, N. O. (1976). Some aspects of the metabolism of Butyrivibrio fibrisolvens. Journal of General Microbiology 97, 105-111.

WhITE, R. W. (1969). Viable bacteria inside the rumen ciliate Entodinium caudatum. Journal of General Microbiology 56, 403-408. 